\title{
TELÍTETLEN TALAJOK JELLEMZŐINEK VIZSGÁLATÁRA ALKALMAS LABORATÓRIUMI BERENDEZÉS FEJLESZTÉSE
}

\section{THE DEVELOPMENT OF LABORATORY EQUIPMENT FOR TESTING THE CHARACTERISTICS OF UNSATURATED SOILS}

\author{
Botoș Marius Lucian ${ }^{1}$, Gobesz Ferdinánd-Zsongor ${ }^{2}$, Kisfaludi-Bak Zsombor ${ }^{3}$ \\ ${ }^{1}$ Kolozsvári Müszaki Egyetem, Épitömérnöki Kar, Tartószerkezetmechanikai Tan- \\ szék, 400027, Románia, Kolozsvár, Gh. Baritiu u. 25, I. em., 147, Tel. +40-264- \\ 401517,marius.botos@mecon.utcluj.ro \\ ${ }^{2}$ Kolozsvári Müszaki Egyetem, Épitömérnöki Kar, Tartószerkezetmechanikai Tan- \\ szék, 400020, Románia, Kolozsvár, C. Daicoviciu u. 15, III. em., 305, Tel. +40-264- \\ 401351,go@mecon.utcluj.ro \\ ${ }^{3}$ Kolozsvári Müszaki Egyetem, Épitömérnöki Kar, Tartószerkezetmechanikai Tan- \\ szék, 400027, Románia, Kolozsvár, Gh. Baritiu u. 25, I. em., 147, Tel. +40-264- \\ 401517,zsombi_kisfaludi@yahoo.com
}

\begin{abstract}
The laboratory assessment of the hydraulic characteristics of unsaturated soils usually requires expensive equipment and extended time period. In lack of financial support, but taking advantage of local knowledge and resources, the development of cheaper alternative equipment is presented in the present paper. The automated setup allows the assessment of the saturation degree of soil samples subjected to different suctions.
\end{abstract}

Keywords: laboratory, equipment, testing, unsaturated, soil, water.

\section{Összefoglalás}

A telítetlen talajok hidraulikus jellemzőinek a méréséhez laboratóriumi környezetben költséges felszerelés és hosszú idő szükséges. Pénzügyi fedezet hiányában, de kihasználva a helyi forrásokat és tudást, egy olcsóbb alternatív berendezés kifejlesztése kerül ismertetésre e dolgozatban. Az automatizált felszerelés különböző szívóhatásoknak alávetett talajminták telítettségi fokát hivatott értékelni.

Kulcsszavak: laboratórium, berendezés, vizsgálat, telítetlen, talaj, víz.

\section{Bevezetés}

A földböl készült építmények viselkedését a talajvíz döntően befolyásolhatja. A talajba jutó vízmennyiségre a szivárgások vizsgálatából lehet következtetni, melyeket fúráspróbákkal, illetve gyakorlati és elméleti módszerek kombinálásával lehet véghezvinni. Különösen fontos ilyen vizsgálatokat végezni olyan földépítményeknél, ahol a biztonság a cél. Ingatag lejtők csapadék általi átitatódása, mosódása, vagy ingadozó 
vízmennyiségü tározók esetében, e számításokhoz alkalmazott peremfeltételek jelentős változása megkövetelheti, hogy telítetlen talajok vizsgálata történjen. Ilyen és hasonló esetekben, a hidraulikus jellemzők meghatározása (telítettségi fok, vízvisszatartó és tároló képesség, különféle szívásokra jellemző permeabilitási együtthatók, stb.) a kezdeti lépés. Ezeket a jellemzőket többféle képen lehet meghatározni, így például közvetlen laboratóriumi módszerekkel, stacionárius [1] vagy nem-stacionárius körülmények között [2], vagy akár közvetlenül a terepen [3]. Akkor akadnak számítási problémák, amikor a telítettségi görbékhez közeli értékek adódnak [4 - 6], melyek feletti rész a talaj telítettségét mutatja.

Mivel a közvetlen eljárások igen hoszszadalmasak és költségesek, szinte természetszerüleg, több közvetett módszer lett kifejlesztve a talajok hidraulikus jellemzőinek a kiszámítására a WRC (vízvisszatartási görbe) meg a SWCC (talaj-víz jelleggörbe) alapján [7 - 10].

E görbék laboratóriumi meghatározásához is elég komoly felszereltség és tapasztalt személyzet szükséges. Gipsz elemekhez vagy fém rudakhoz csatlakoztatott villamos vagy hő érzékelők, valamint feszültség mérők segítségével alkalmazzák a tengelyeltolási módszerrel [11], mely által különböző nyomásokat lehet létrehozni és fenntartani addig, amíg kialakul a gáz-víz egyensúly. Villamos- vagy hő érzékelők hiányában is alkalmazható a tengelyeltolási módszer, például talajpróbákra fektetett szürőpapírral észlelve a nedvességet különböző nyomási szinteken.

\section{Számítási folyamat}

Mint ismeretes, a nem permanens mozgást telítetlen közegekben Richard egyenletével lehet meghatározni, ahol $k_{x}(h), k_{y}(h)$ és $k_{y}(h)$ a hidraulikus vezetőképességi tényezők; $C(h)$ pedig a kapilláris kapacitás (mindegyik a $h$ szívás függvényében):

$$
\begin{array}{r}
\frac{\partial}{\partial x}\left(k_{x}(h) \frac{\partial h}{\partial x}\right)+\frac{\partial}{\partial y}\left(k_{y}(h) \frac{\partial h}{\partial y}\right)+ \\
+\frac{\partial}{\partial z}\left(k_{z}(h) \frac{\partial h}{\partial z}\right)=C(h) \frac{\partial h}{\partial t}
\end{array}
$$

A telítettségi fokot az alábbi képlet alapján lehet megállapítani:

$$
S_{e}=\frac{\theta-\theta_{r}}{\theta_{s}-\theta_{r}}
$$

ahol $\theta_{s}$ jelöli a nedvességet telített állapotban (90-92\%) és $\theta_{r}$ a reziduális nedvesség tartalmat (1500 kPa szívás után a talajmintában visszamaradt nedvesség).

A $\theta$ nedvesség tartalmat, vagy a $S_{e}$ telítettségi fokot a tengelyeltolási kísérleti módszerrel lehet különböző szintü szívóhatásokra megállapítani.

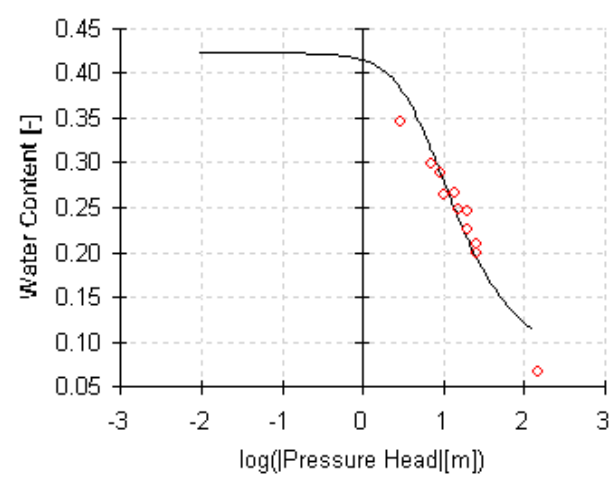

1. ábra. Egy „, $\Theta$ vs. $\log h ”$ jelleggörbe.

Ahhoz, hogy egy deriválható kifejezéshez jussunk, az 1. ábrán látható függvény alakja folytonos kell legyen. Ezt közelítő képletek kiválasztásával és alkalmazásával lehet elérni.

A szakirodalom által kínált változatok közül az alábbi két változatra esett a választás:

Brooks és Corey [10]:

$$
S_{e}=(\alpha|h|)^{-\lambda}
$$


Illetve, van Genuchten [7]:

$$
\begin{aligned}
& S_{e}=\left[1+(\alpha|h|)^{n}\right]^{-m} \\
& S_{e}=\left[1+(\alpha|h|)^{n}\right]^{-(1-2 / n)} \\
& S_{e}=\left[1+(\alpha|h|)^{n}\right]^{-(1-1 / n)}
\end{aligned}
$$

A problémát részben megoldottnak lehet tekinteni akkor, amikor az $\alpha$ és $\lambda$, illetve az $\alpha, m$ és $n$ paraméterek értékét úgy sikerül meghatározni, hogy a telítettségi fokot leíró $S_{e}(h)$ függvény minél pontosabban fedje a kísérleti mérések eredményeit (2. ábra).

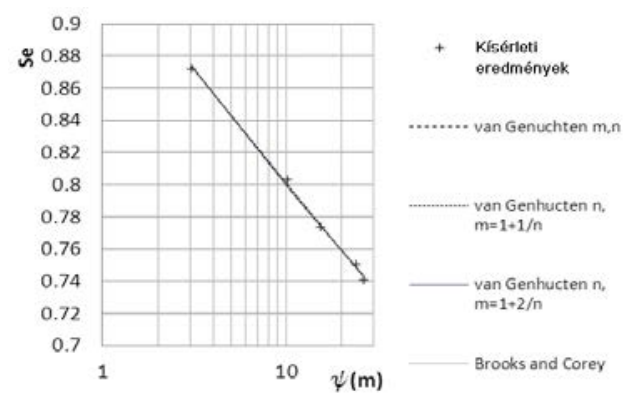

2. ábra. Egy számítási sorozat eredményeinek az összevetése a kísérleti mérésekkel.

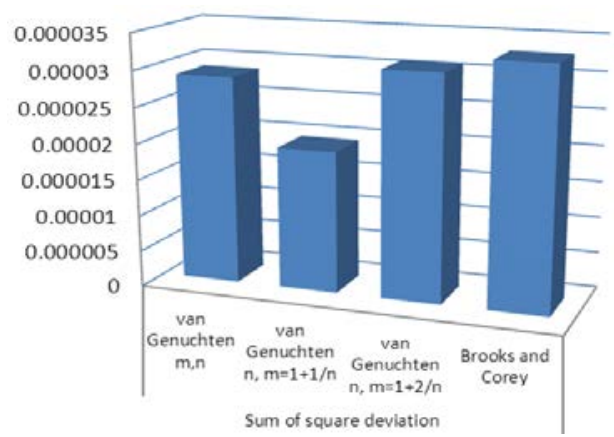

3. ábra. A közelitő képletek alkalmazásából eredö eltérések összehasonlitása.

Miután sikerül kiválasztani azt a modellt, amelyik a legjobban közelíti meg a kísérleti mérési adatokat, az említett alakparamétereket felhasználhatjuk a $k_{r}$ relatív hidraulikus vezetőképesség kiszámításához.
Brooks és Corey képlete a Burdine modell [12] esetében a következő alakot ölti:

$$
k_{r}=S_{e}^{l+1+2 / \lambda}
$$

Illetve a Mualem modell [10] esetében:

$$
k_{r}=S_{e}^{l+2+2 / \lambda}
$$

Van Genuchten képlete a Burdine [12] modell alkalmazása esetén:

$$
k_{r}=S_{e}\left[1-\left(1-S_{e}^{1 / n}\right)^{n}\right]
$$

Illetve, a Mualem [10] modellre írva:

$$
k_{r}=S_{e}\left[1-\left(1-S_{e}^{1 / n}\right)^{n}\right]^{2}
$$

A telítetlen talaj szivárgási tényezője úgy lesz kiszámítva, hogy a telített közeg szivárgási tényezője meg lesz szorozva a (4a) - (4d) egyenletek egyikével kiszámított relatív szivárgási tényezővel.

A 4. ábrán látható a vízvisszatartási görbék meg a Brooks és Corey féle alaki paraméterek alapján becsült szivárgási tényező változása a Burdine, illetve a Mualem modell esetén.

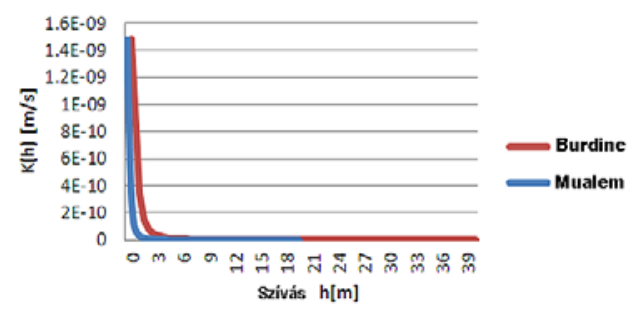

4. ábra. A szivárgási tényező változása a szívó értékek függvényében (a Burdine és a Mulaem modell alkalmazásakor).

\section{Mérőberendezés}

A közvetlen módszerek alkalmazásához meg kell határozni a talaj-víz jelleggörbéket, illetve a telített állapotra jellemző szivárgási tényezőt, az előző fejezetben leírtak alapján, laboratóriumi környezetben. 
Porózus és laza talajoknál konstans gradiensü, míg csekély vízáteresztő képességü talajmintáknál változó gradiensü permeamétert használnak e célra. A telített állapotra jellemző szivárgási tényező kiszámításához az alábbi képlet alkalmazható (Darcy törvényéből indulva ki, mely többféleképpen írható, attól függően, hogy mely értékeket mérjük):

$$
q=v \cdot A=K_{t e l} \cdot i \cdot A
$$

Ebben a képletben $q$ az áramlási intenzitás (áteresztett vízmennyiség), $K_{\text {tel }}$ a szivárgási tényező (más néven hidraulikus vezető-képesség) telített állapotban, $i$ a hidraulikus gradiens és $A$ a vízáteresztő metszet mérete (a $v$ pedig a vonalmenti sebesség).

Az áramlási intenzitást a tömeg vagy a térfogat alapján is meg lehet állapítani (például egy precíziós mérleg vagy büretta segítségével). Konstans gradiensü permeaméter esetében:

$$
q=\frac{V}{\Delta t}=\frac{m \cdot g}{\gamma \cdot \Delta t}
$$

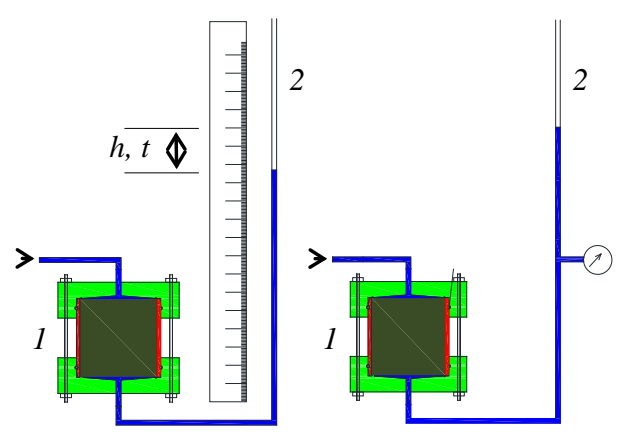

5. ábra. Kézi meg automata adatrögzitésü permeaméter sémája $(1-a$ telített talajmintát tartalmazó kamra, 2 - átlátszó csö).

Amennyiben a nyomásméröt a próbatestbe folyó víz szintjében helyezzük el (5. ábra), a hidraulikus gradiens értéke a kijelzett $p$ nyomás meg a próbatest $L$ hosszának a függvényében, az alábbi képlettel számítható ki:

$$
i=\frac{p}{\gamma \cdot L}
$$

Kézi adatrögzítés esetében (5. ábra) az előbbi képlet így alakul:

$$
i=\frac{h}{L}
$$

Változó gradiensü permeaméter alkalmazása esetén a $d$ átmérőjü (átlátszó) csőben észlelhető $\Delta h$ szintkülönbség alapján lehet kiszámítani az áramlási intenzitást:

$$
q=\frac{\Delta h \cdot \pi \cdot d^{2}}{4 \cdot \Delta t}
$$

Nyomásmérő használata esetén az előbbi képlet a következő alakban írható:

$$
q=\frac{\Delta p \cdot \pi \cdot d^{2}}{\gamma \cdot 4 \cdot \Delta t}
$$

A tengelyeltolási módszerhez ugyanazokat a berendezéseket lehet használni mint a telített közegekben mért permeabilitáshoz, de víz helyett levegő kerül a talajmintát tartalmazó kamra bemenetébe és a szürőket egy HAES (High Air Entry Stone) lappal helyettesítik az alsó kimenetnél (6. ábra).

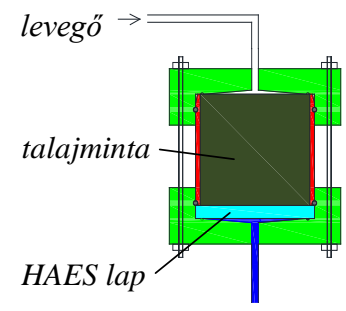

6. ábra. Telítetlen talajok permeabilitásának a méréséhez használható kamra sémája.

Ez a lap, a pórusainak a mérete és alakja révén, meggátolja a levegő áthaladását egy bizonyos (gyártási jellemzőként megadott) 
nyomásig. A talajpróbában levő víz viszont kijuthat ezen a lapon keresztül addig, amíg közvetlenül érintkezik vele (a kísérleti kamrába való helyezése előtt ezért telített állapotban kel legyen a HAES lap).

A talajmintán átszivárgó vízmennyiséget természetesen mérni lehet (mint már említve volt, akár elektronikus mérleggel, akár egy precíziós bürettával), így megállapítható az áramlási intenzitás.

Az egyensúlyi állapot meghatározásához szükséges légnyomás beállítása és fenntartása egy szabályozóval történik, de alacsony szívóértékek esetén ezt elég nehéz megvalósítani. Ilyen esetekben (20-30 kPa alatti szívásra) egy nyomásgerjesztő nélküli berendezést lehet alkalmazni, úgy, hogy a kamrában levő légköri nyomáshoz képest állandó szívóhatás keletkezzen a HAES lap alján. Ezt az állandó értékü szívóhatást a legegyszerübben egy kimeneti túlfolyóval lehet biztosítani (a távozó víz szintjének a változatlanságával).

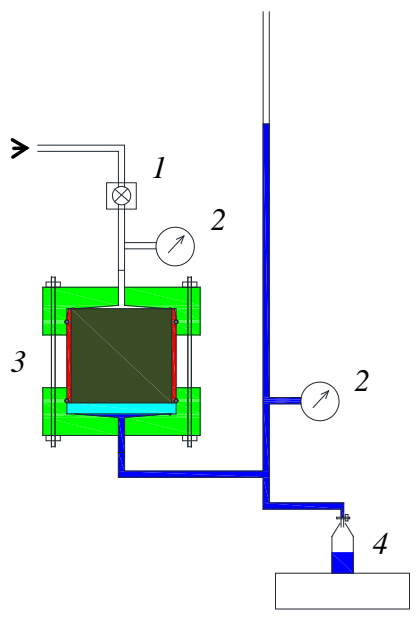

7. ábra. Telítetlen talajminták mérését szolgáló automatizált berendezés sémája $(1-a$ mikrokontroller által vezérelt nyomásszabályozó; 2 - a mikrokontrollerhez csatlakoztatott nyomásérzékelö; $3-a$ telítetlen talajmintát tartalmazó kamra, a HAES lappal alul; 4 - a mikrokontrollerhez csatlakoztatott mérleg).
Ezek a mérési ciklusok igen hosszadalmas folyamatokat képeznek és az egyensúlyi állapot észleléséhez jelenlétet meg időszakos ellenőrzéseket igényelnek, ezért nem árt az automatizálásuk. Az automatizálás akkor válik igazán szükségessé, amikor több talajmintán kell végezni párhuzamosan méréseket, mivel ilyen esetekben a nyomások beállítása meg az egyensúlyi állapotok észlelése igen figyelmes gondoskodást és nagyon sok időt igényel. A 7. ábrán látható egy ilyen automatizált berendezés sémája, mely egy mikrokontroller segítségével van vezérelve.

\section{Megvalósítás és alkalmazás}

Az elöbbiekben ismertetettek alapján, a tanszékünk vízépítési laboratóriumában egy olyan automatizált berendezést sikerült kialakítani, melyen egyszerre több talajminta hidraulikus jellemzőit meg lehet kapni anélkül, hogy emberi felügyelet lenne szükséges hozzá.

Kétféle kísérleti kamra lett készítve, egy nagyobb, acélköntösü (8. és 9. ábra), meg hat darab kisebb, müanyag, illetve plexi köntösü (10. ábra). A nagyobb méretü, acélköntösü kamra akár 15 bar nyomást is el tud viselni, míg a kisebb kamrák csak 3 bar nyomásig voltak próbálva.
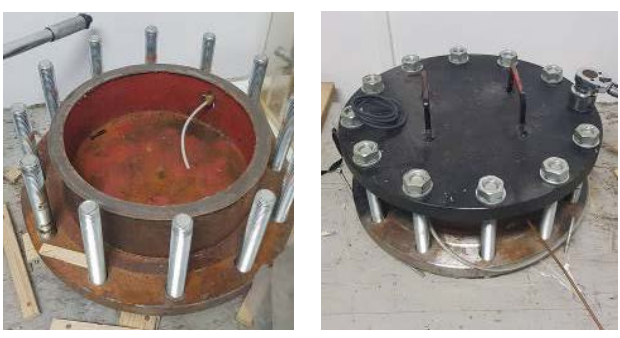

8. ábra. A nagyobb nyomásnak alávetett telítetlen talajminták permeabilitását mérö kamra képei (balra szétszerelve, jobbra lezárt állapotban).

A 10. ábrán látható az egyik kisebb nyomásnak alávetett telítetlen talajminták permeabilitását mérő kamra (a 6. ábrán 
látható séma szerint megvalósítva). A plexi talpon keresztül látható a HAES lap és a tömítő gyürü, a kamra mellett pedig a precíziós büretta is.

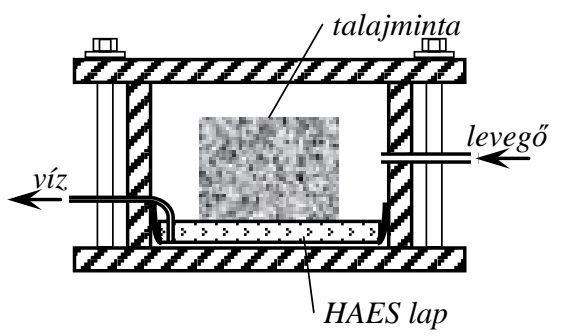

9. ábra. A nagyobb nyomásnak alávetett telítetlen talajminták permeabilitását mérö kamra metszete.

A költségesebb komponensek a HAES lapok voltak (11. ábra), mivel a laboratórium már fel volt szerelve kompresszorral.

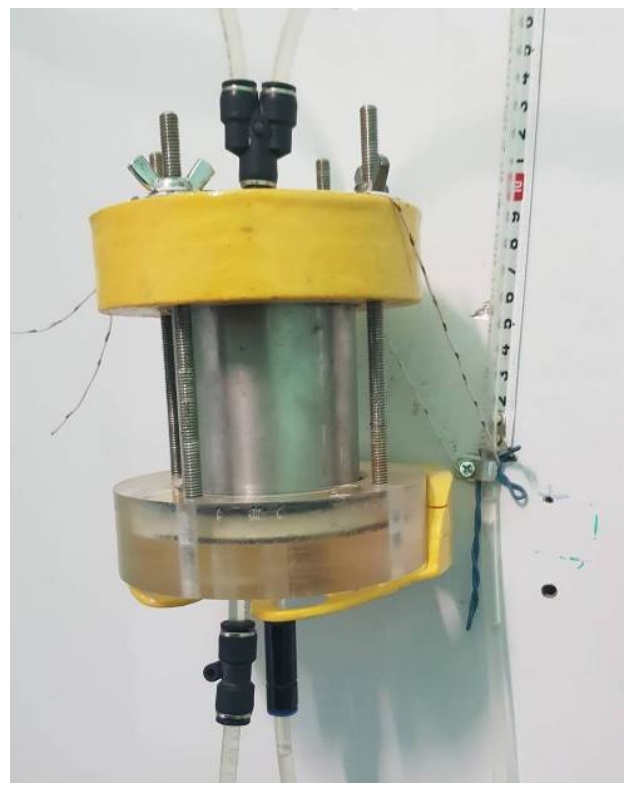

10. ábra.Az egyik kisebb kísérleti kamra.

Az automatizálás egy programozható „element14 BeagleBone Black” [13, 14] egységgel lett kialakítva, mely $1 \mathrm{GHz}$-es ARM Cortex A8-as processzorral, 512 MB memóriával és 4 GB tárkapacitással volt ellátva (12. ábra). Az egység programozásával Simon Zsolt számítástechnikai mérnökhallgató foglalkozott kitartóan.

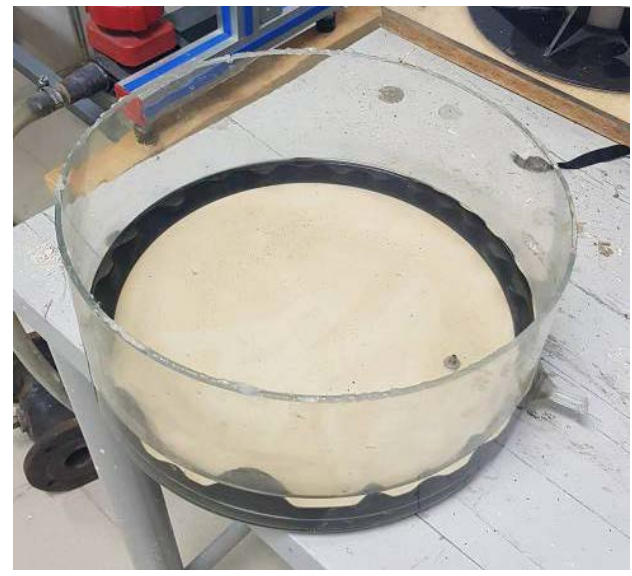

11. ábra. A nagyobb HAES lap áztatás (telítés) közben.

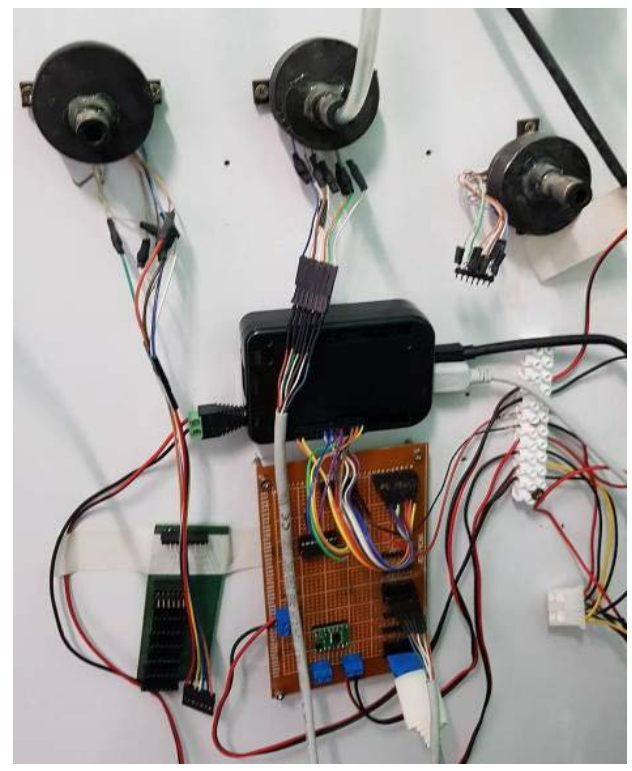

12. ábra.A mikrokontrolleres egység (néhány csatlakozással, felette 3 nyomásérzékelö is látható).

Az első változatban egy számítógéphez volt csatlakoztatva a mikrokontrolleres egy- 
ség, és akár tíz talajminta párhuzamos méréseit is képes volt ellátni, az alábbi lépéseket vezérelve:

- nyomásszabályozás (különböző értékeken, végighaladva minden beütemezett mérési szakaszon);

- a bürettában vagy a piezométerben levő víz szintjének a mérése (az áramlási intenzitás megállapításához, valamint ahhoz, hogy mikor lehet a következő nyomásszintre térni);

- a mágnesszelepek párhuzamos vezérlé-se (ezek segítségével lehet pontosan mérni mindegyik talajmintában külön-külön a vizet, minden mért és lementett egyensúlyi szintre);

- az adatok továbbítása egy adatbázisba, majd a jelleggörbék megjelenítése;

- a telítettségi fokot ábrázoló függvény folytonosságához leginkább alkalmas egyenletet kiválasztó algoritmus futtatása, az egyezési paraméterek meghatározásával;

- az összes hidraulikus jellemző kiszámítása és a változási görbék ábrázolása;

- minden nyomástartományra megalkotja és lementi a kiszivárgó térfogatok időbeli változási görbéit, hogy meg lehessen határozni a diffúzivitást;

- értesítést küld a meghatározások bevégzéséről talajmintákként (e-mail üzenettel).

Ez a rendszer megengedte a külső beavatkozást is (vezérlést, monitorizálást) egy webes felületen keresztül.

Utólagos fejlesztések eredményeként a köztes számítógépet is sikerült kiiktatni a rendszerből, a mikrokontrolleres egységet közvetlen HDMI csatlakozással kötve egy kijelzőhöz.

A jelenlegi felállásban három kisméretű (alacsony nyomású) permeaméter müködik párhuzamosan a nagyobb nyomást bíró, acélköntösű kamrával (a rendelkezésre álló HAES lapok korlátozott száma miatt). Ezeknek a kamráknak egy kompresszor biztosítja a szükséges légnyomást, melyet a mikrokontroller által vezérelt nyomásszabályozó alegységek (12. ábra) által lehet kamránkként különböző szintekre állítani.

A közeljövőben az acélköntösü kamrában ki lesz cserélve a HAES lap alól kiszivárgó vizet elvezető mủanyag cső egy neoprén csőre, illetve a bemeneti nyomás is acél csövön keresztül lesz (mivel véleményünk szerint a jelenlegi rézcső képlékenysége befolyásolhatja a méréseket).

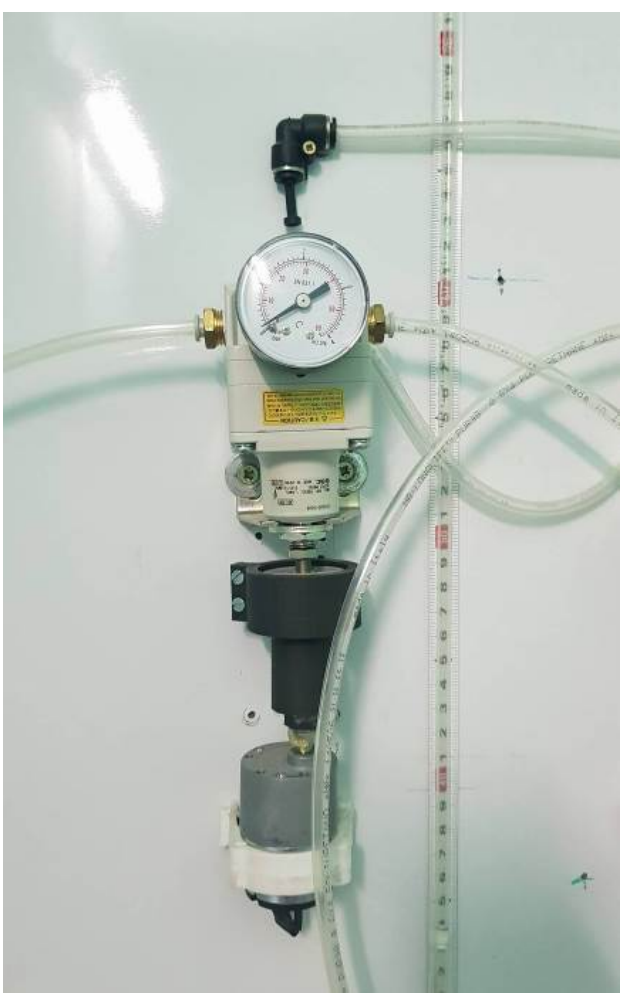

12. ábra.Egy nyomást mérö és vezérlö alegység (a háttérben egy bürettával).

\section{Következtetések}

Aránylag kis költségekkel (és lelkes munkával) sikerült létrehozni egy olyan kísérleti berendezést, mellyel olyan mérések végezhetök el, mint a jól felszerelt laboratóriumokban. Ezáltal bővült a kutatási lehetőségek palettája is. 
A létrehozott kísérleti berendezés eddigi müködése azt mutatja, hogy a kutatási munkát végző hallgatók mellett a gyakorló szakemberek is eredményesen igénybe vehetik a telítetlen talajok vizsgálatához.

Az automatizálásnak köszönhetően a mérések hosszantartó ideje alatt nem szükséges az emberi jelenlét és beavatkozás. Komoly időmegtakarítást jelent az is, hogy több kísérleti mérést és számítást lehet párhuzamosan végezni (ezek számát még bővíteni lehet a jövőben)

A berendezés, a telítetlen talajok hidraulikus jellemzőinek a jelleggörbéken keresztüli meghatározása mellett arra is lehetőséget kínál, hogy a különböző talajminták gázáteresztési képességével, nyírási ellenállásával, vagy hővezetési képességével kapcsolatos kérdésekkel is foglalkozni lehessen.

\section{Szakirodalmi hivatkozások}

[1] Klute, A.: Laboratory measurement of hydraulic conductivity of unsaturated soil. Methods of Soil Analysis, Mono. 9, Part 1. American Society of Agronomy, Madison, WI, USA, 1965, 253 - 261.

[2] Hamilton, J. M., Daniel, D. E., Olson, R. E.: Measurement of hydraulic conductivity of partially saturated soils. Permeability and Groundwater Contaminant Transport. ASTM Special Tech. Publ. 746, 1981, 182 - 196.

[3] Watson, K. K.: An instantaneous profile method for determining hydraulic conductivity of unsaturated porous materials. Water Resources Research 2, 1966, 709-715 oldal.

[4] Gardner, W. R.: Calculation of capillary conductivity from pressure plate out flow data. Soil Science Society of America Proceedings 20, 1956, 317-320.

[5] Benson, C. H., Gribb, M.: Measuring unsaturated hydraulic conductivity în the laboratory and field. (Eds: Houston, S., Fredlund, D. G.), Unsaturated Soil Engineering Prac- tice. American Society of Civil Engineers Special Technical Publication No. 68, Reston, VA, 1997, 113-168.

[6] Leij, F. J., van Genuchten, M. T.: Characterization and measurement of the hydraulic properties of unsaturated porous media. (Eds.: van Genuchten, M.Th., Leij, F.J., Wu, L.), Proceedings of International Workshop, Characterization and Measurements of the Hydraulic Properties of Unsaturated Porous Media. University of California, Riverside, CA, 1999, 31-42.

[7] Brooks, R. H., Corey, A. T.: Hydraulic properties of porous medium. Hydrology Paper 3. Colorado State University, Fort Collins, USA, 1964.

[8] Fredlund, D. G., Xing, A., Huang, S.: Predicting the permeability function for unsaturated soil using the soil - water characteristic curve. Canadian Geotechnical Journal 31, 1994, 533-546.

[9] Mualem, Y.: A new model for predicting the hydraulic conductivity of unsaturated porous media. Water Resources Research 12 (3), 1976, 513-522.

[10] van Genuchten, M. T.: A closed-form equation for predicting the hydraulic conductivity of unsaturated soils. Soil Science Society of America Journal 44, 1980, 892-898.

[11] Vanapalli S. K., Nicotera M.V., Sharma R.S.: Axis translation and negative water column techniques for suction control. Laboratory and Field Testing of Unsaturated Soils, Springer, 2009, 33-49.

[12] Burdine, N. T.: Relative Permeability Calculations From Pore Size Distribution Data, Transactions of the American Institute of Mining \& Metallurgical Engineers, 198, 1953, $71-78$.

[13] Coley, G.: element14 BeagleBone Black System Reference Manual, Premier Farnell, 2014, https://cdn.sparkfun.com/datasheets/ Dev/Beagle/e14 BBB_SRM_rev 0.9.pdf (hozzáférés: 2017.október).

[14] https://beagleboard.org/bone (hozzáférés: 2017.október). 